\begin{abstract}
McNatt, Regan Allison. Hypoxia-induced growth rate reduction in two juvenile estuary-dependent fishes. (Under the direction of J ames A. Rice)
\end{abstract}

As eutrophication of coastal waters increases, water quality issues such as hypoxia have come to the for efront of environmental concerns in North Carolina. Many fisheries in North Carolina are dependent on estuaries for essential nursery habitat. Chronic hypoxia during the summer has become a common occurrence in North Carolina estuaries, increasing the exposure of juvenile fish to hypoxic conditions.

I conducted a laboratory study to investigate how various degrees of hypoxia affect growth rates of juvenile spot (Leiostomus xanthurus) and Atlantic menhaden (Brevoortia tyrannus) at two different temperatures. For a two-week period I exposed fish to one of four constant dissolved oxygen (DO) levels $\left(6.0,4.0,2.0\right.$, or $1.5 \mathrm{mg} \mathrm{O}_{2} \mathrm{l}^{-1}$ ), at one of two temperatures (25ㄷ $\mathrm{C}$ $30^{\circ} \mathrm{C}$ ). A fifth DO treatment, included for spot at $30^{\circ} \mathrm{C}$, allowed DO to fluctuate from $10.0 \mathrm{mg} \mathrm{O}_{2} \mathrm{I}^{-1}$ during the day to $2.0 \mathrm{mg} \mathrm{O}_{2} \mathrm{l}^{-1}$ at night. This diel fluctuation follows the natural DO cycle in tidal estuarine creeks. Growth measurements were recorded at the beginning, middle, and end of experiments. In all trials, growth rates at $1.5 \mathrm{mg} \mathrm{O}_{2} \mathrm{I}^{-1}$ were significantly lower than growth rates in the 6.0, 4.0, $2.0 \mathrm{mg} \mathrm{O}_{2} \mathrm{I}^{-1}$, and fluctuating 
treatments. The reduction in growth rate ranged from 31\% to $89 \%$ among trials.

Hypoxia is often associated with fish kills, which attract attention in the media and research. However, sublethal levels of hypoxia typically are more prevalent and may affect fish on a more frequent basis. Hypoxia does not need to be lethal to have detrimental effects on juvenile estuarydependent fishes. 


\title{
Hypoxia-induced growth rate reduction in two juvenile estuary-dependent fishes.
}

\author{
by \\ Regan Allison McNatt \\ A thesis submitted to the Graduate Faculty of \\ North Carolina State University \\ In partial fulfillment of the requirements for the \\ Degree of Master of Science
}

Fisheries and Wildlife

Raleigh

2002

Approved by:

J ames A. Rice, Chair 
To my parents,

for their everlasting and unconditional love and support. 


\section{Biography}

In Fredericksburg, Virginia on J une 26, 1976 I was born to Milton and Trudy McNatt, the second of two daughters. Although we moved to three different houses when I was growing up, we never left F redericksburg. In fact, all of our moves were to houses within a quarter-mile radius of each other.

My big move came when it was time for college. I only applied to one university and in the fall of 1994 I started my freshman year at The University of North Carolina at Chapel Hill. GO HEELS! Moving from such a small community to such a large university would have been a shock, but luckily my older sister, Heather, had al ready made the transition from Fredericksburg to UNC - Chapel Hill and helped me settle in.

While at school in Chapel Hill I had my first taste of scientific research when I secured an internship at UNC-CH's Institute of Marine Sciences in Morehead City, North Carolina. During my internship I learned how difficult field research can be when Hurricane Bertha blew out all of my pit traps from the saltwater marshes. The following year I became an undergraduate laboratory technician for Drs. David and Karin Pfennig, working on kin recognition and mate-choice selection in spadefoot toads. For the next two summers I was their field technician at the Southwestern Research Station in Portal, Arizona. While there I was able to conduct some of my own studies 
on spadefoot toads for my senior research project. With my BS degree in Biology in hand the next move was to graduate school.

I almost overlooked NC State as an option for my graduate study but I am glad that I did not. Although it meant being ridiculed (jokingly - I hope) by my family and new colleagues here at NC State, my time here has been invaluable. 


\section{Acknowledgements}

First I would like to thank my Father for giving me his scientific mind, and my Mother for balancing me out with her intuition so that I am not as insanely methodical as Dad is.

I owe thanks to so many people who have been involved in this project in one way or another. I must start by thanking my advisor Dr. J ames A. Rice who has al ways been encouraging and supportive of my work and has always had time to answer my questions no matter how simple or complex. Thanks also to my committee members Dr. William Swallow for his statistical advice, and Dr. J oseph Hightower for keeping me true to my research.

Funding was provided by North Carolina Sea Grant, and facilities were graciously provided by the National Marine Fisheries Service Beaufort Laboratory. I must acknowledge the biologists and staff at the NMFS Iab, without whose help I would not have made it this far, including Dr. Don Hoss, Dr. J ohn Burke, Pete Crumley, Harvey Walsh, Gary Fisher and Randy Ferguson. A portion of this project was conducted at The University of Delaware's College of Marine Studies and I thank Dr. Tim Targett and Kevin Stierhoff for the use of their facilities and all of their help during my visit. A special thanks to Dr. Paul Grecay for encouraging me to push the limit just to see what happens at 1.5 . 
To my technicians, Deb Squires, Holly Preston, Brian Stynes, and Bill Hettler, thank you for your help, your advice, your humor, and your patience. You are most deserving of my gratitude. I also thank those who helped me in the lab or field when I was short-handed or just to keep me company, Robert Aguilar, Katey Marancik, and Kevin Craig. Thanks to Chris Taylor and Trevor Yip-Hoi who provided invaluable help and advice on how to survive in the Radiation Building and how to whip DO levels into submission.

Thanks to my friends at NC State and especially to all my roommates who have both kept me sane and made me insane these past three years. Finally, I give special thanks to Robert Aguilar (Lil' Robbie) and J ason Robinson (J Rob) my fellow year-class. Thank you for listening to me complain and then complaining right back at me, thank you for laughing at my stupid jokes and then making me die with laughter at your dry and sometimes disturbing humor, and thank you for making me feel not so bad about my procrastination skills; we all work better under pressure. I could not have survived this last year without either of you. It has been a pleasure sharing the basement of Clark Labs with you. 


\section{Table of Contents}

List of Figures.............................................................................

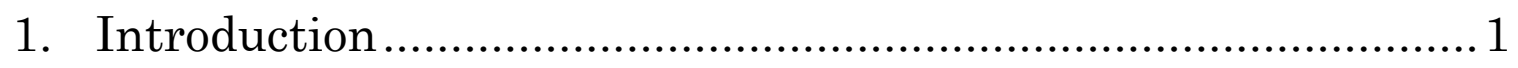

2. Materials and Methods .........................................................

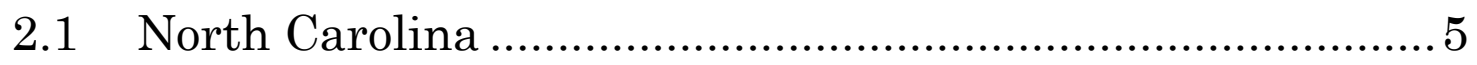

2.1.1 Experimental Set-up ..................................................

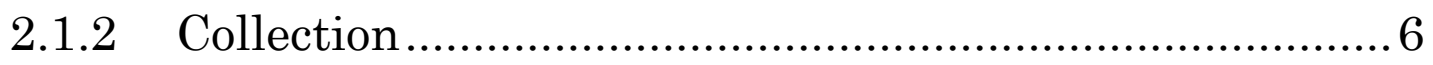

2.1.3 Procedures ..................................................................

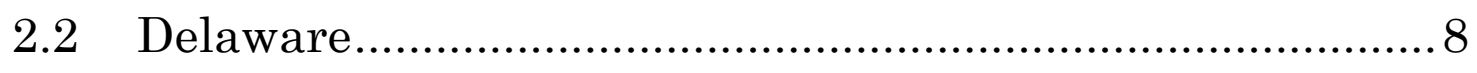

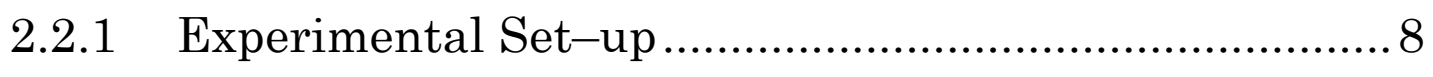

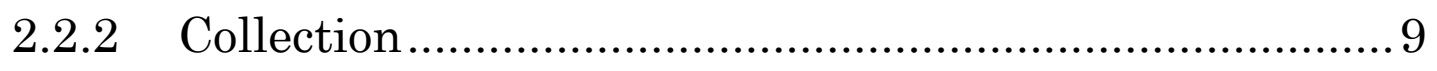

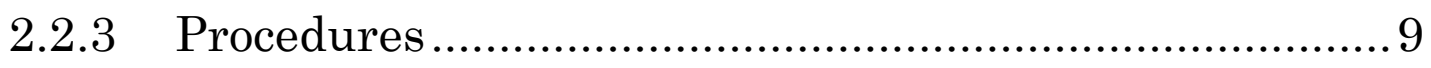

2.3 Analysis ............................................................................ 10

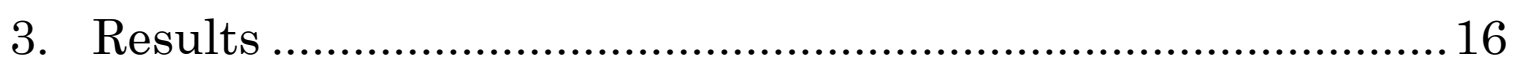

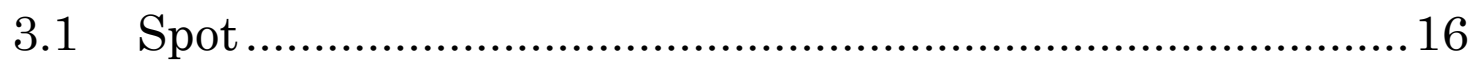

3.2 Atlantic Menhaden ............................................................ 17

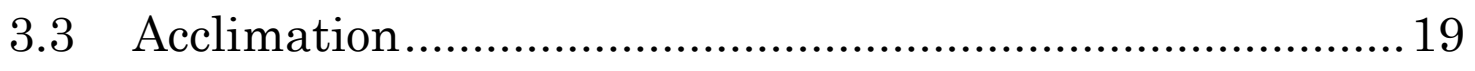

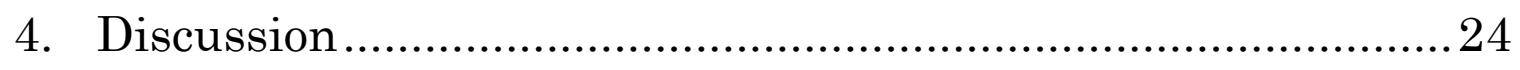

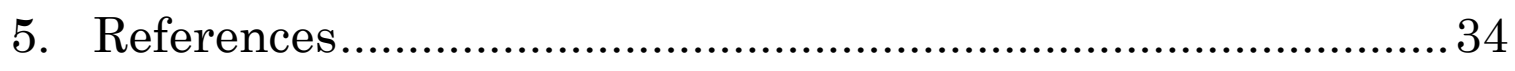




\section{List of Figures}

Figure 2.1 Schematic of recirculating seawater system in

Beaufort, NC

Figure 2.2 Example of DO pattern in Beaufort, NC lab................12

Figure 2.3 Rounders made of fiberglass sheeting..........................13

Figure 2.4 Schematic diagram of recirculating seawater system in

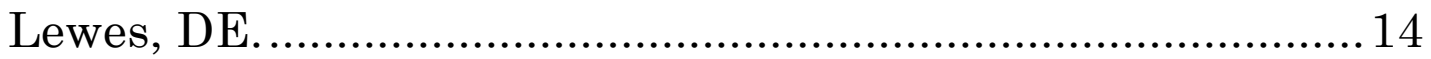

Figure 2.5 Example of DO pattern in Lewes, DE lab.................... 15

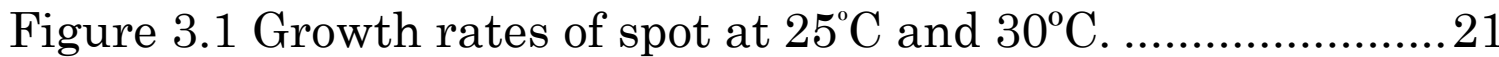

Figure 3.2 Growth rates of Atlantic menhaden at $25^{\circ} \mathrm{C}$ and $30^{\circ} \mathrm{C}$.

Figure 3.3 Evidence of acclimation in spot and Atlantic menhaden. 


\section{Introduction}

Anthropogenic nutrient input to coastal waters has been increasing over recent years leading to a greater frequency, severity, and duration of bottom-water hypoxia worldwide (Rosenberg, et al., 1992; Diaz and Rosenberg, 1995 and references therein). In a comprehensive study of U.S. estuaries, Bricker et al. (1999) found that $65 \%$ of estuaries examined showed symptoms of moderate or high eutrophication and they estimated that the condition of over half of the nation's estuaries will decline in the next 20 years. In coastal North Carolina, bottom-water hypoxia is a seasonal phenomenon. During late summer and early fall, the water column stratifies along thermal and salinity-driven density gradients, limiting mixing between surface and bottom waters. Benthic fauna and decomposing organic matter eventually deplete the bottom water of dissolved oxygen (DO). Mixing only occurs during strong winds or storms, thus, hypoxic conditions can last a few days or weeks (Pihl, et al., 1991; Pihl, 1994; Eby, 2001). Anthropogenic nutrient loading into estuaries exacerbates the problem by increasing the biological oxygen demand.

Estuaries provide essential nursery habitat for many marine fish of ecological and economic importance (Weinstein, 1979). Hypoxia is an environmental perturbation to which juvenile estuary-dependent fish are being increasingly exposed. The effects of hypoxia most acknowledged by the 
media and researchers are fish kills, however, estuarine fish are more commonly exposed to levels of hypoxia that are sublethal. How fish respond to sublethal hypoxia is more difficult to quantify due to varying effects on individual organisms' behavior and physiology (Kramer, 1987; Crocker and Cech, 1997; Wannamaker and Rice, 2000; Taylor, 2001) and effects on estuarine ecosystem dynamics (Breitburg, et al., 1997; Eby, 2001).

Most marine hypoxia investigations concentrate on infauna and benthic macrofauna (Dauer, et al., 1992; Pihl, et al., 1992; Rosenberg, et al., 1992; Pihl, 1994; Diaz and Rosenberg, 1995; Nestlerode and Diaz, 1998; Taylor and Eggleston, 2000). Another suite of studies focuses on activity level and respiration (Schurmann and Steffensen, 1994; Crocker and Cech, 1997; Schurmann and Steffensen, 1997; Domenici, et al., 2000). There also have been field surveys (Pihl, et al., 1991; Howell and Simpson, 1994; Eby, 2001) and laboratory trials (Deubler and Posner, 1963; Weltzien, et al., 1999; Wannamaker and Rice, 2000) which indicate that mobile species are able to detect and avoid hypoxia. However, the ability to detect and avoid hypoxia does not guarantee that mobile species will not encounter hypoxia for a prolonged period of time. When hypoxic conditions develop, fish may become trapped in low-oxygen waters or the hypoxia may be so pervasive that fish cannot escape, thus, they may be exposed to hypoxia for extended periods (Rosenberg, et al., 1992; Paerl, et al., 1998; 1999). 
While there are a few laboratory studies that examine potential effects of prolonged hypoxic exposure on growth rate of juvenile fish, most of the focal species are flatfish (Bejda, et al., 1992; Petersen and Pihl, 1995; Taylor, 2001) or species that do not represent a large portion of estuarine fish biomass (Secor and Gunderson, 1998). The objective of this study was to examine how sublethal hypoxia affects juvenile spot (Leiostomus xanthurus) and Atlantic menhaden (Brevoortia tyrannus), two highly abundant estuarine fish species. These species constitute a large percentage of estuarine fish biomass and are forage fish for many commercially and recreationally prized species (Weinstein, 1979). Additionally there is a large commercial fishery for adult Atlantic menhaden.

Larvae and postlarvae of spot and Atlantic menhaden migrate into estuaries during early spring after being spawned in the winter off the coast of North Carolina. Peak migration of spot occurs in late February to early April (Weinstein, 1979; Warlen and Chester, 1985). Peak migration of Atlantic menhaden lags about one month behind peak spot migration, in accordance with the timing of peak spawning (Weinstein, 1979; Rogers and Van Den Avyle, 1983; Warlen and Chester, 1985). Juveniles of both species spend the summer in the estuaries feeding on benthic meiofauna or plankton then migrate back out to shelf waters (Rogers and Van Den Avyle, 1983; Hales and Van Den Avyle, 1989). As they leave the estuaries, they take with 
them the energy and nutrients they have assimilated from the estuarine system. Thus, spot and Atlantic menhaden, as well as other nonresident estuarine species, are essential in coupling estuarine systems to nearshore ocean environments through energy transfer (Weinstein, 1979; Weinstein, et al., 1980; Gottlieb, 1998). This coupling mechanism is especially important in lagoonal estuary systems, like North Carolina's estuaries, where tidal flushing potential is limited (Stanley, 1992).

Spot and Atlantic menhaden represent two functional groups, demersal and pelagic, whose growth under hypoxic conditions has yet to be quantified in a controlled laboratory setting. I proposed to examine growth rates of juvenile spot and Atlantic menhaden exposed to different levels of DO at two temperatures at which both species are likely to encounter hypoxia. I chose various degrees of hypoxia to determine if there is a graded or threshold response to DO and I chose two temperatures because of the lower solubility of oxygen and the higher metabolic rate of fish at higher temperatures. Each trial was conducted for a two-week period. It is not unusual for hypoxic conditions to persist for this amount of time, and the timeframe allowed me to examine whether spot and Atlantic menhaden are able to acclimate to sublethal hypoxia. 


\section{Materials and Methods}

This project was part of an inter-institutional Sea Grant endeavor between North Carolina State University, The University of Delaware, and Louisiana State University. I conducted three experiments at NOAA's National Marine Fisheries Service Laboratory in Beaufort, North Carolina. One trial was conducted at the University of Delaware's hypoxia lab, located at the Graduate College of Marine Studies in Lewes.

\subsection{North Carolina}

\subsubsection{Experimental Set-up}

The Beaufort lab (Figure 2.1) consisted of twelve 62-l experimental tanks incorporated into a recirculating seawater system (Taylor, 1999). The tanks' exteriors were covered with black plastic sheeting to prevent the fish from reacting to my presence. To reduce diffusion at the air-water interface, lids made of insulation board were floated on top of the water and foam stripping was used as a gasket to seal the edges of the insulation board. The lids had a $17-\mathrm{cm}$ diameter window sealed with clear plastic sheeting to provide lighting, and a $4.5^{-} \mathrm{cm}$ hole that was sealed with a plastic stopper through which the DO probe was inserted into the tanks for measurements and through which food was delivered. There were four DO treatment levels, 1.5, 2.0, 4.0, and $6.0 \mathrm{mg} \mathrm{O}_{2} \mathrm{l}^{-1}$, respectively representing $20,26,53$, and $79 \%$ 
oxygen saturation at $25^{\circ} \mathrm{C}$, and $22,29,56$, and $86 \%$ oxygen saturation at $30^{\circ} \mathrm{C}$. There were three replicates of each treatment level. DO concentrations were maintained by a series of countercurrent water-nitrogen gas exchange columns (Fry, 1951; Taylor, 1999). The amount of DO in the water was indirectly proportional to the amount of nitrogen bubbled into the water. DO concentrations were monitored hourly and adjustments were made to the nitrogen flow until the treatment levels reached their target DO concentration. Once target DO levels were achieved, they remained stable, with little variation (Figure 2.2).

\subsubsection{Collection}

Juvenile spot and Atlantic menhaden were collected from coastal

waters near Beaufort, North Carolina and transported to NOAA's National Marine Fisheries Service Laboratory in Beaufort, North Carolina during June and July 2001. Spot were captured using a 7.6-m, 6-mm mesh bag seine and held in a flow-through $4.8 \times 1.8 \times 0.7-\mathrm{m}$ concrete tank at ambient salinities (31-35 ppt). They were fed a pelleted feed while in the holding tanks. Atlantic menhaden were collected using a 1.5 -m cast net with a $6-\mathrm{mm}$ mesh and were held in a circular (1.8-m diameter, $0.8 \mathrm{~m}$ deep) flow-through fiberglass tank at a salinity of 15 ppt. They were fed a crumble feed. 


\subsubsection{Procedures}

At the beginning of each trial, fish were transported from the holding tanks to the experimental tanks. The salinity was decreased from $31 \mathrm{ppt}$ to 15 ppt over the course of 50 minutes for spot. Spot are a euryhaline species and did not respond negatively to this rate of salinity change. Atlantic menhaden were already being held at the experimental salinity (15 ppt). Four juvenile spot (average standard length $\pm \mathrm{SD}, \mathrm{SL}=66 \pm 4 \mathrm{~mm}$; average wet weight $\pm \mathrm{SD}$, wet wt. $=7.1 \pm 1.4 \mathrm{~g}$ ) or six juvenile Atlantic menhaden (average SL $=73 \pm 9 \mathrm{~mm}$, average wet wt. $=7.7 \pm 2.7 \mathrm{~g}$ ) were randomly placed in each tank. Whenever Atlantic menhaden were in the experimental tanks I added "rounders" made of flexible fiberglass sheeting to the tanks (Figure 2.3) to facilitate the natural schooling behavior of Atlantic menhaden. The fish were given one week to acclimate to the experimental tanks, salinity, temperature (either 25 or $30^{\circ} \mathrm{C}$, maintained by controlling the air temperature), photoperiod (14L:10D), and the feeding schedule. Spot were fed to excess (5 $\mathrm{g}$ of chopped shrimp and $1 \mathrm{~g}$ of chopped clams) each day. Atlantic menhaden were also fed to excess ( $1 \mathrm{~g}$ of floating crumble feed $\{100-$ 200 micron, $60 \%$ protein $\}$ four times per day). Leftover food was removed daily by either netting out the shrimp and clams or siphoning the crumble feed out of the tanks. A $10 \%$ water change was performed every other day to ensure good water quality; water chemistry $\left(\mathrm{pH}\right.$, alkalinity, $\mathrm{NH}_{3} / \mathrm{NH}_{4}{ }^{+}, \mathrm{NO}_{2}$, 
and $\mathrm{NO}_{3}{ }^{-}$) was evaluated once per week. Once the $\mathrm{DO}$ treatment began and target concentrations were achieved, DO was measured and recorded four times each day throughout the experiments using a YSI Model 52 DO meter which was calibrated using the air saturation method before each use; membranes were changed between experiments. Fish were weighed and measured (wet wt., SL, total length $\{\mathrm{TL}\}$ ) at the beginning, middle and end of the treatment. Mortalities were removed from the tanks, weighed, and measured.

\subsection{Delaware}

\subsubsection{Experimental Set-up}

The Lewes lab consisted of five recirculating seawater systems, each with ten 11-l experimental tanks (Figure 2.4). This arrangement allowed five DO treatments, with 10 replicates per treatment, to be run simultaneously. To reduce diffusion at the air-water interface, tanks were covered with clear plastic sheeting. There were four constant DO treatment levels, 1.5, 2.0, 4.0, and $6.0 \mathrm{mg} \mathrm{O}_{2} \mathrm{l}^{-1}\left(22,29,56\right.$, and $86 \% \mathrm{O}_{2}$ saturation, respectively), and a fluctuating treatment. In the fluctuating treatment DO concentrations varied from $10.0 \mathrm{mg} \mathrm{O}_{2} \mathrm{l}^{-1}\left(144 \% \mathrm{O}_{2}\right.$ saturation) during the day to $2.0 \mathrm{mg} \mathrm{O}$ $\mathrm{l}^{-1}$ at night. This pattern mimics the natural DO cycle in shallow estuarine creeks where photosynthesis provides plenty of oxygen during the day, and respiration uses much of the DO at night. The daily average DO of the 
fluctuating treatment was $6.0 \mathrm{mg} \mathrm{O}_{2} \mathrm{l}^{-1}$, allowing comparison with the constant $6.0 \mathrm{mg} \mathrm{O}_{2} \mathrm{l}^{-1}$ treatment level. DO levels were monitored, recorded, and adjusted by a computer-controlled complex of solenoid valves and a Strathkelvin 781 DO meter (Grecay and Stierhoff, manuscript submitted). DO levels were maintained close to their target concentrations (Figure 2.5).

\subsubsection{Collection}

In May 2001, juvenile spot were collected from coastal waters near Beaufort, North Carolina using a 7.6-m, 6-mm mesh bag seine. The fish were transported to the Graduate College of Marine Studies in Lewes, Delaware in an aerated 300-l fiberglass tank. There they were held in flow-through fiberglass tanks, at $30^{\circ} \mathrm{C}$ and a salinity of $15 \mathrm{ppt}$, and were fed a pelleted feed until needed for experimentation.

\subsubsection{Procedures}

Four juvenile spot (average SL $=50 \pm 4 \mathrm{~mm}$, average wet wt. $=3.0 \pm$

$0.7 \mathrm{~g}$ ) were randomly chosen to be placed in each experimental tank. The fish were already acclimated to the experimental temperature, maintained by controlling the air temperature, and salinity $\left(30^{\circ} \mathrm{C}\right.$ and $\left.15 \mathrm{ppt}\right)$. The fish were fed chopped shrimp once daily at a rate of $0.8 \mathrm{~g}$ per fish, and were given one week to acclimate to the tanks and feeding schedule. The feeding rate was adjusted for mortalities and to ensure feeding to excess. Leftover food was removed at the end of the day by netting out remaining shrimp. Water 
chemistry ( $\mathrm{pH}$, alkalinity, $\mathrm{NH}_{3} / \mathrm{NH}_{4}{ }^{+}, \mathrm{NO}_{2}{ }^{-}$, and $\mathrm{NO}_{3}{ }^{-}$) was evaluated once per week. DO levels were monitored, recorded and adjusted by the computer every five minutes. Fish were weighed and measured (wet wt., SL, TL) at the beginning, middle and end of the treatment. Mortalities were removed from the tanks, weighed and measured.

\subsection{Analysis}

Data were analyzed separately for each species. All analyses were performed on wet weight data that had been converted to grams gained per

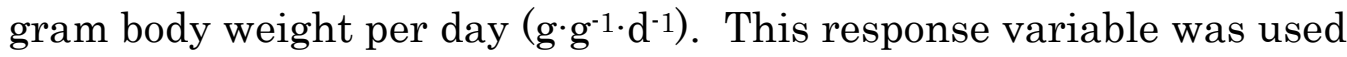
because it is most indicative of fish growth and condition. All fish that died were excluded from analyses. I used the General Linear Models procedure in SAS, with DO, temperature, and their interaction as factors. In cases where there was a significant effect, I did pair-wise comparisons using the least significant difference (LSD) with a significance level of $\alpha=0.05$ to test for differences among the treatment means. I also examined the effect of tank to ensure that growth was not biased by tank location and that I did not have a tank with exceptionally fast or slow growing fish. By using my repeated measurements as a factor nested within DO and temperature, I assessed whether there was an effect of time on growth. Such an effect would indicate whether growth rates worsened with continued exposure to hypoxia, or whether growth rates improved, indicating acclimation. 


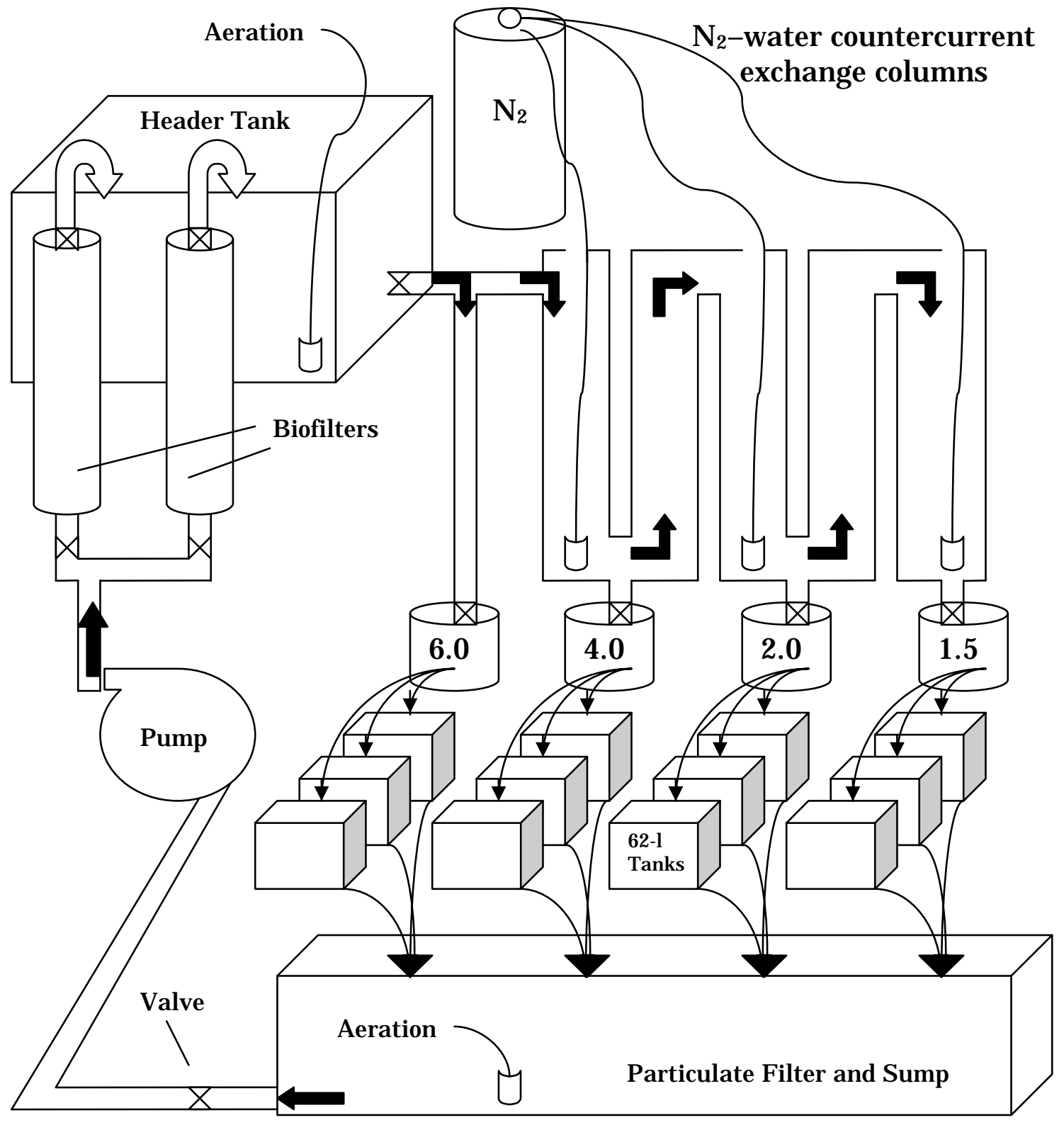

Figure 2.1 Schematic of recirculating seawater system in Beaufort, NC.

Water flowed from the header tank through a series of $\mathrm{N}_{2}$-water countercurrent exchange columns, which controlled DO concentrations. From the columns water flowed into the experimental tanks. Overflow from the tanks was directed through a particulate filter and into a sump. Water was then pumped through a biofilter, back to the header tank. 


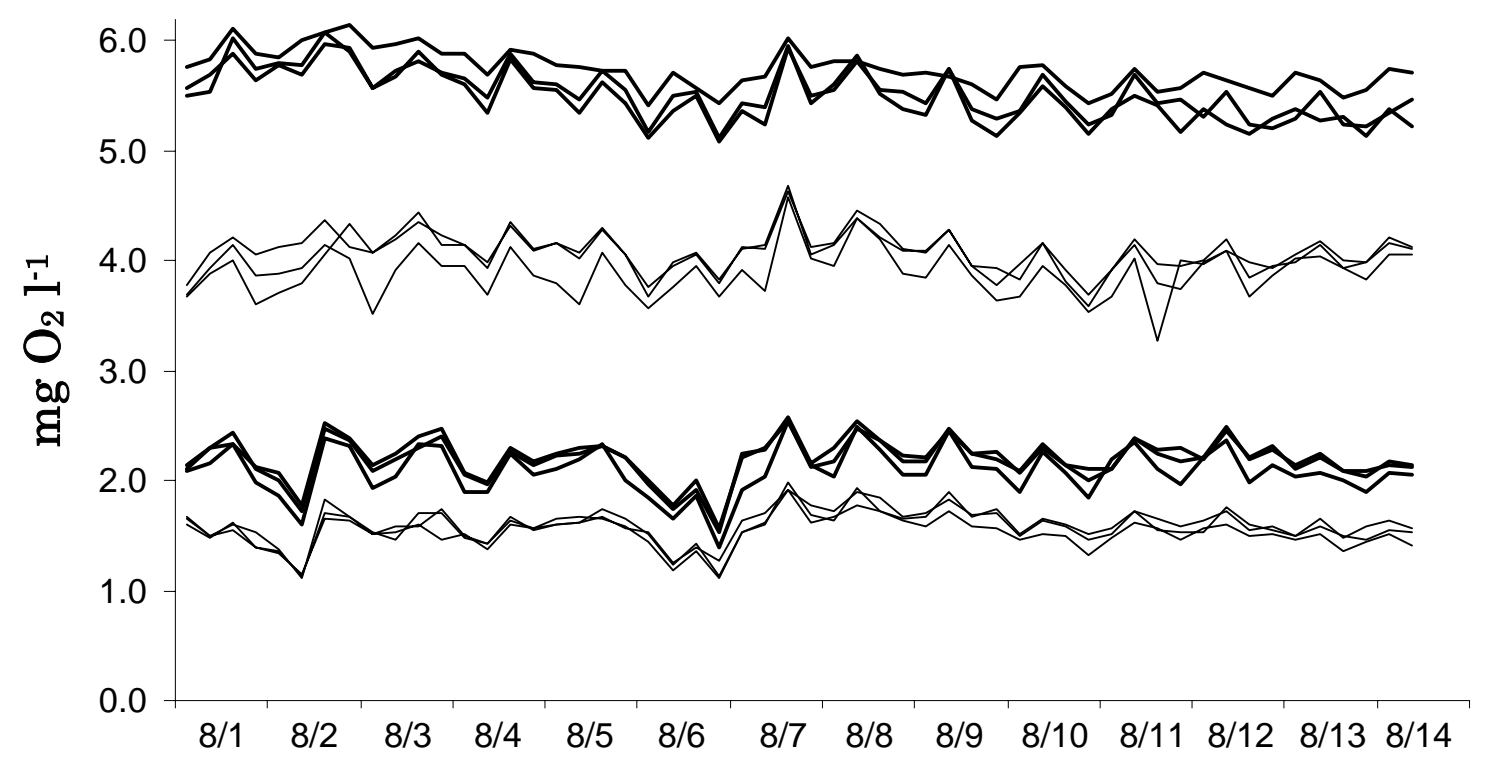

Figure 2.2 Example of DO pattern in Beaufort, NC lab.

A graphical representation of DO levels during an August 2001 trial in Beaufort, NC. The three lines at each target DO level indicate replicates of that treatment level. 


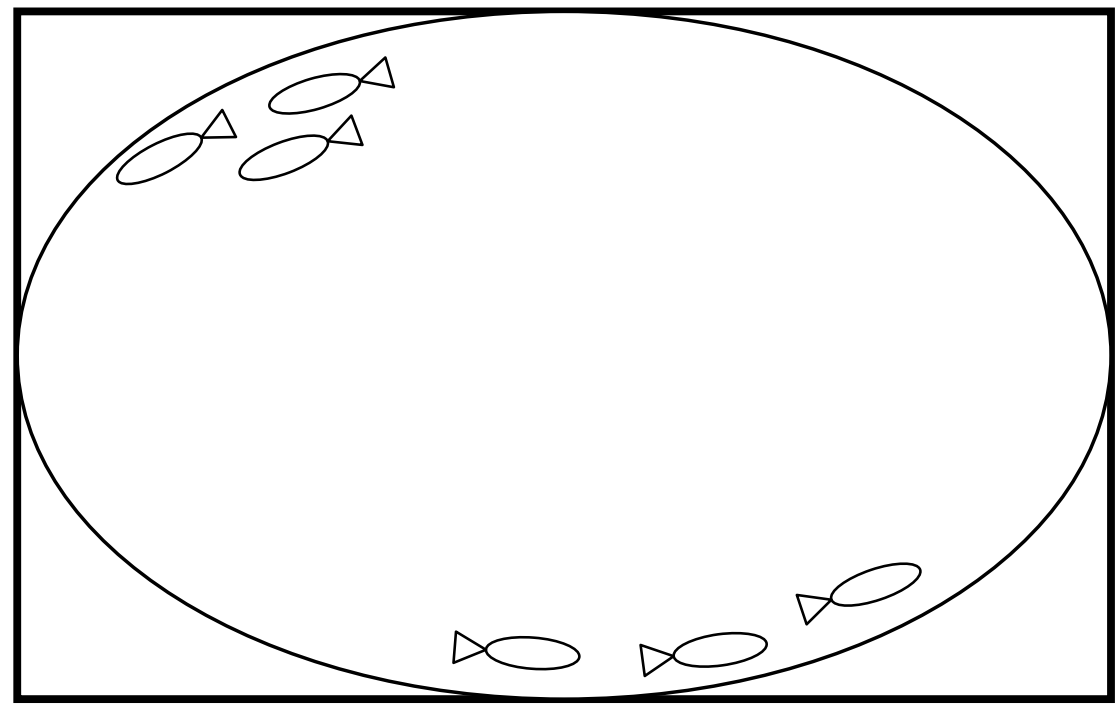

Figure 2.3 Rounders made of fiberglass sheeting. These were placed in experimental tanks with Atlantic menhaden to facilitate natural schooling behavior and prevent crowding in the corners of the tanks. 


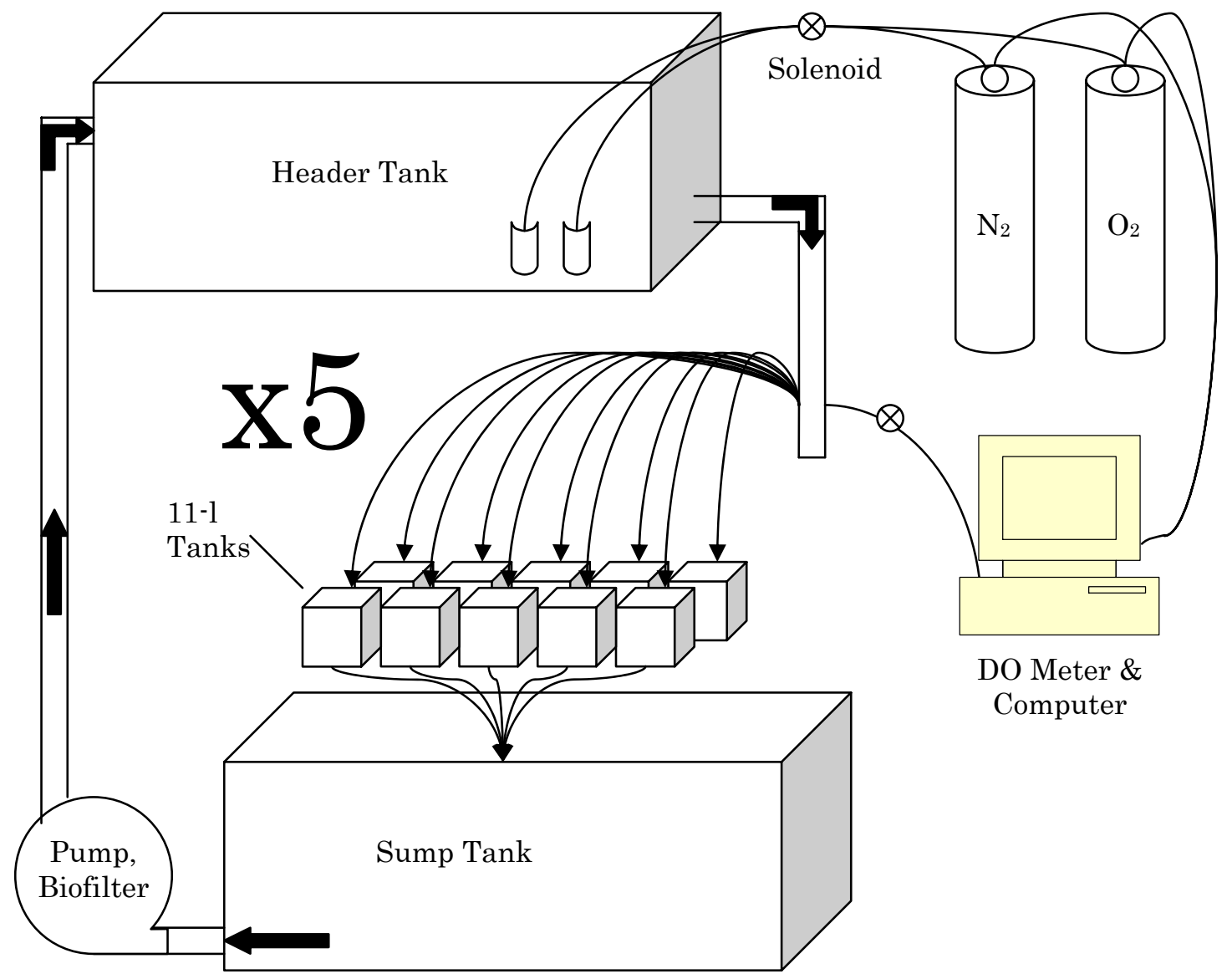

Figure 2.4 Schematic diagram of recirculating seawater system in Lewes, DE.

Water flowed from the header tank into the experimental tanks. Overflow from the tanks was collected in a common sump and pumped through a biofilter and back to the header tank. There were five of these recirculating water systems. DO levels were monitored and adjusted by a single DO meter and computer. A complex of solenoids would allow the DO meter to sample water, sequentially, from each of the five systems. The DO reading was analyzed by the computer software and nitrogen or oxygen was pumped into the header tank to maintain target DO levels. 


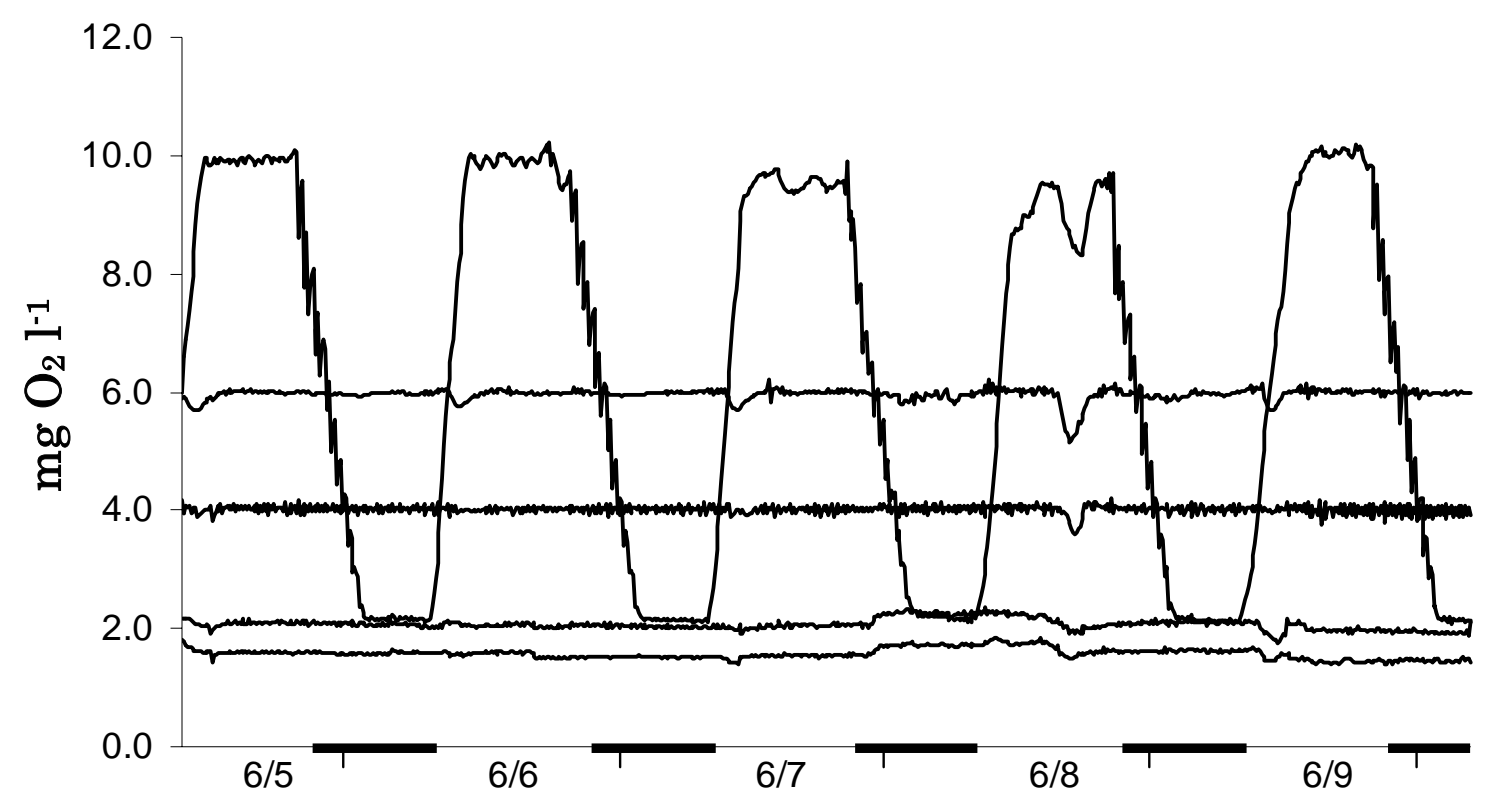

Figure 2.5 Example of DO pattern in Lewes, DE lab.

A graphical representation of DO levels during the Lewes, DE trial, 2001. There were four constant DO levels and a

fluctuating level which mimicked natural DO cycles in shallow estuarine creeks. The dark bars on the $\mathrm{x}$ axis represent nighttime. 


\section{Results}

\subsection{Spot}

Both temperature and DO affected growth rates of spot over the twoweek duration of exposure $\left(06 / 01 / 01-06 / 15 / 01\right.$, spot $30^{\circ} \mathrm{C} ; 07 / 06 / 01-$ 07/20/01 spot $25^{\circ} \mathrm{C}$ ). Temperature had a significant effect on growth rates as might be expected based on bioenergetic considerations; spot grew faster at $25^{\circ} \mathrm{C}$ than at $30^{\circ} \mathrm{C}(\mathrm{p}=0.0065$, Figure 3.1$)$. The fact that growth rates decreased from $25^{\circ} \mathrm{C}$ to $30^{\circ} \mathrm{C}$ suggests that $30^{\circ} \mathrm{C}$ is higher than the thermal optimum for growth of spot. At $30^{\circ} \mathrm{C}$ there was a $36,16,12$, and $90 \%$ decrease in growth at $6.0,4.0,2.0$, and $1.5 \mathrm{mg} \mathrm{O}_{2} \mathrm{l}^{-1}$, respectively.

Oxygen concentration also had a significant effect on spot growth rates ( $p=0.0002$, Figure 3.1). Pair-wise comparisons of means using the LSD indicated that spot in the $1.5 \mathrm{mg} \mathrm{O}_{2} \mathrm{l}^{-1}$ treatment grew significantly slower than in all other treatments levels. These results suggest a threshold effect of DO, with no reduction in growth until DO was reduced to the lowest level (Figure 3.1). I examined the results in further detail and evaluated the effects of DO at each temperature. I specifically compared the growth rates at $6.0 \mathrm{mg} \mathrm{O} \mathrm{O}^{-1}$, which was most indicative of normoxic conditions, to growth rates at $1.5 \mathrm{mg} \mathrm{O}_{2} \mathrm{l}^{-1}$, where there was a substantial decrease in growth. At $25^{\circ} \mathrm{C}$, the average growth rate of spot was $2.2 \% \cdot \mathrm{d}^{-1}$ in the $6.0 \mathrm{mg} \mathrm{O}_{2} \mathrm{l}^{-1}$ treatment, and the average growth rate was $1.5 \% \cdot \mathrm{d}^{-1}$ at $1.5 \mathrm{mg} \mathrm{O}_{2} \mathrm{l}^{-1}$, 
resulting in a $31 \%$ growth rate reduction. At $30^{\circ} \mathrm{C}$, the average growth rate of spot was $1.4 \% \cdot \mathrm{d}^{-1}$ at $6.0 \mathrm{mg} \mathrm{O} \mathrm{l}^{-1}$, while at $1.5 \mathrm{mg} \mathrm{O}_{2} \mathrm{l}^{-1}$ the average growth rate was $0.2 \% \cdot \mathrm{d}^{-1}$ yielding an $89 \%$ growth rate reduction (Figure 3.1 ). The $89 \%$ reduction at $30^{\circ} \mathrm{C}$ was a significant reduction $(\mathrm{p}=0.05)$ and was the primary cause of the overall DO effect seen across temperatures. The growth rate of spot in the fluctuating treatment, which had a mean daily average oxygen concentration of $6.0 \mathrm{mg} \mathrm{O}_{2} \mathrm{l}^{-1}$, did not differ from the growth rate of spot in the constant $6.0 \mathrm{mg} \mathrm{O}_{2} \mathrm{l}^{-1}$ treatment, nor did it differ from that observed in the 2.0 or $4.0 \mathrm{mg} \mathrm{O}_{2} \mathrm{l}^{-1}$ treatments. However, it did differ from the $1.5 \mathrm{mg} \mathrm{O}_{2} \mathrm{l}^{-1}$ treatment (Figure 3.1). Similar DO response curves are seen at both $25^{\circ} \mathrm{C}$ and $30^{\circ} \mathrm{C}$ (Figure 3.1), and there was not a significant interaction between DO and temperature.

\subsection{Atlantic Menhaden}

Atlantic menhaden growth also responded to both temperature and DO over the two-week exposure period (08/01/01 - 08/15/01, Atlantic menhaden $30^{\circ} \mathrm{C} ; 08 / 10 / 01-08 / 24 / 01$, Atlantic menhaden $25^{\circ} \mathrm{C}$ ). There was a marginally significant $(\mathrm{p}=0.05)$ interaction between temperature and DO. Temperature appeared to have a greater effect on growth at 2.0 and $4.0 \mathrm{mg} \mathrm{O}_{2} \mathrm{l}^{-1}$, and a lesser influence on growth at the highest and lowest DO levels, 6.0 and 1.5 $\mathrm{mg} \mathrm{O}_{2} \mathrm{l}^{-1}$ (Figure 3.2). With Atlantic menhaden, growth rates were higher at $30^{\circ} \mathrm{C}$ than $25^{\circ} \mathrm{C}(\mathrm{p}=0.0001)$. These results suggest that $30^{\circ} \mathrm{C}$ is closer to the 
optimum growth temperature for Atlantic menhaden. The interacting effect of temperature and $\mathrm{DO}$ could be seen when growth rates at $25^{\circ} \mathrm{C}$ were compared to growth rates at $30^{\circ} \mathrm{C}$. As mentioned above, there was a greater effect of temperature on growth at 2.0 and $4.0 \mathrm{mg} \mathrm{O}_{2} \mathrm{l}^{-1}$ where there was, respectively, a 38 and $35 \%$ increase in growth from $25^{\circ} \mathrm{C}$ to $30^{\circ} \mathrm{C}$.

Temperature had a lesser effect on growth at 1.5 and $6.0 \mathrm{mg} \mathrm{O}_{2} \mathrm{l}^{-1}$, with a 22 and $9 \%$ increase, respectively, from $25^{\circ} \mathrm{C}$ to $30^{\circ} \mathrm{C}$.

While there was a marginally significant interaction between DO and temperature, it was also informative to examine the effect of DO independent of temperature. Overall, DO had a significant effect on growth rates $(\mathrm{p}<$ 0.0001). As for spot, growth rates of Atlantic menhaden were significantly reduced in the $1.5 \mathrm{mg} \mathrm{O}_{2} \mathrm{l}^{-1}$ treatment (Figure 3.2). I examined the effects of DO at $25^{\circ} \mathrm{C}$ and $30^{\circ} \mathrm{C}$ separately, again comparing growth at $1.5 \mathrm{mg} \mathrm{O}_{2} \mathrm{l}^{-1}$ to growth at $6.0 \mathrm{mg} \mathrm{O}_{2} \mathrm{l}^{-1}$, which was the treatment level most indicative of normoxic conditions. I found that the average growth rate of Atlantic menhaden at $25^{\circ} \mathrm{C}$ was $2.6 \% \cdot \mathrm{d}^{-1}$ in the $6.0 \mathrm{mg} \mathrm{O}_{2} \mathrm{l}^{-1}$ treatment, and $1.0 \% \cdot \mathrm{d}^{-1}$ in the $1.5 \mathrm{mg} \mathrm{O}_{2} \mathrm{l}^{-1}$ treatment ( $63 \%$ reduction). At $30^{\circ} \mathrm{C}$, the average growth rate was $2.8 \% \cdot \mathrm{d}^{-1}$ at $6.0 \mathrm{mg} \mathrm{O}_{2} \mathrm{l}^{-1}$, and $1.1 \% \cdot \mathrm{d}^{-1}$ at $1.5 \mathrm{mg} \mathrm{O}_{2} \mathrm{l}^{-1}(60 \%$ reduction). Pair-wise comparisons using the LSD with a significance level of $\alpha=0.05$ indicated that growth rates in the $1.5 \mathrm{mg} \mathrm{O}_{2} \mathrm{l}^{-1}$ treatment at both temperatures were significantly lower than the growth rates of the other DO 
treatments in their respective temperature treatments (Figure 3.2). Additionally, at $25^{\circ} \mathrm{C}$ growth rates at $6.0 \mathrm{mg} \mathrm{O}_{2} \mathrm{l}^{-1}$ were significantly higher than the rates at 4.0,2.0, and $1.5 \mathrm{mg} \mathrm{O}_{2} \mathrm{l}^{-1}$. Thus Atlantic menhaden exhibited a threshold response at $30^{\circ} \mathrm{C}$, as seen at both temperatures with spot, but the high Atlantic menhaden growth rate at $6.0 \mathrm{mg} \mathrm{O}_{2} \mathrm{l}^{-1}$ suggested a graded response to $\mathrm{DO}$ at $25^{\circ} \mathrm{C}$. This difference in response pattern was the driving influence behind the significant interaction between DO and temperature.

\subsection{Acclimation}

My experimental design allowed me to determine growth rates for 1week intervals and examine whether there was a difference in growth from week 1 to week 2 . If growth rates in week 2 were slower than growth rates in week 1 it would suggest that hypoxia had an increasingly deleterious effect. If, instead, growth rates were higher in week 2 it would suggest that fish were acclimating to the DO treatment. Using the effect of "week" as a main factor nested in DO and temperature, I found that there was no significant difference in growth rates between weeks for spot or Atlantic menhaden. This result makes sense because DO usually only affected growth at one of four (or five) DO treatment levels, so overall there should be little or no difference in growth rates from week 1 to week 2 . Therefore I examined growth rates in the only treatment level where DO consistently impacted 
growth: $1.5 \mathrm{mg} \mathrm{O}_{2} \mathrm{l}^{-1}$. In every trial, growth rate at $1.5 \mathrm{mg} \mathrm{O}_{2} \mathrm{l}^{-1}$ during week 2 was higher than growth rate in week 1 (Figure 3.3). This result suggests that fish experiencing $\mathrm{DO}$ of $1.5 \mathrm{mg} \mathrm{O}_{2} \mathrm{l}^{-1}$ are able to partially adapt to the stress of low DO. 


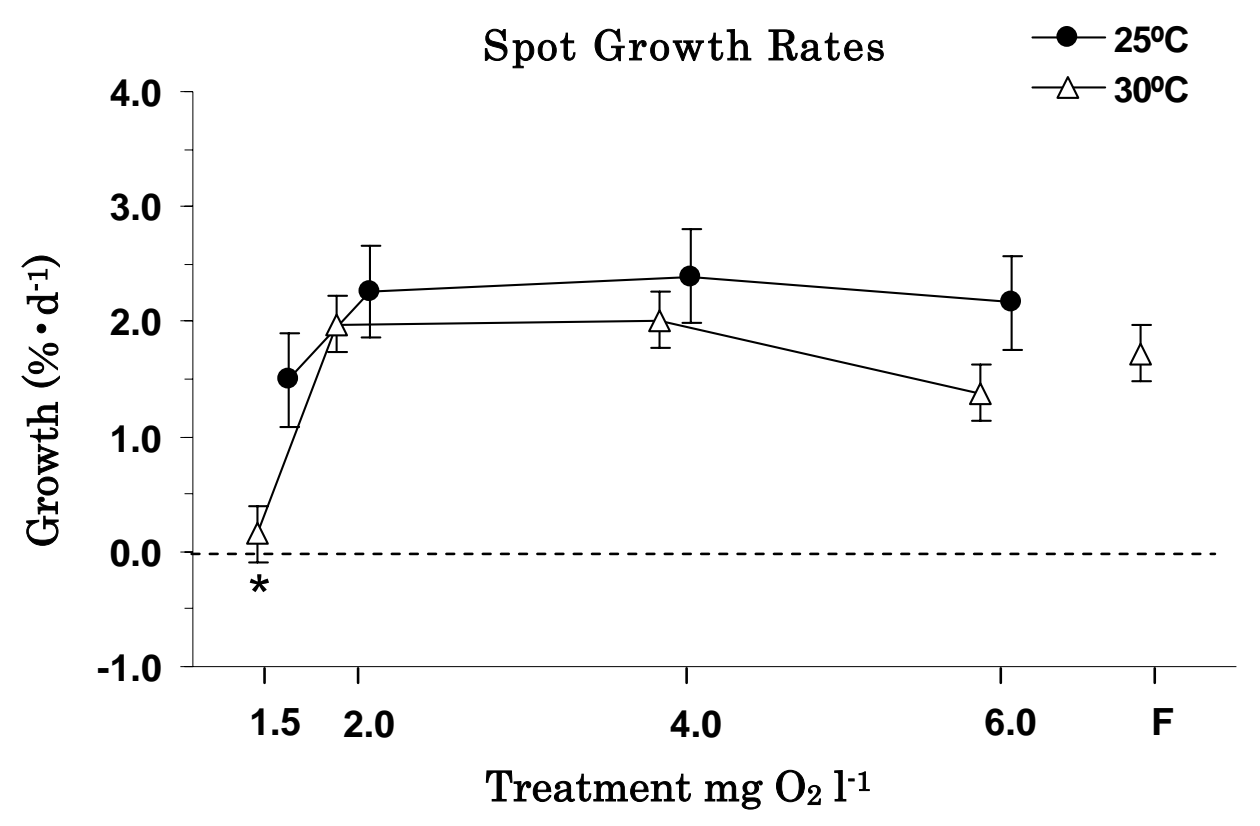

Figure 3.1 Growth rates of spot at $25^{\circ} \mathrm{C}$ and $30^{\circ} \mathrm{C}$. Spot grew faster at $25^{\circ} \mathrm{C}$ (solid circles), than at $30^{\circ} \mathrm{C}$ (open triangles), $\mathrm{p}=0.0065$. Overall growth rates were reduced at 1.5 $\mathrm{mg} \mathrm{O} \mathrm{l}^{-1}, \mathrm{p}=0.0002$. This effect was primarily due to the effect of low DO at $30^{\circ} \mathrm{C}$ where growth was significantly reduced by $89 \%$, as indicated by the asterisk, $\mathrm{p}=0.05$. 


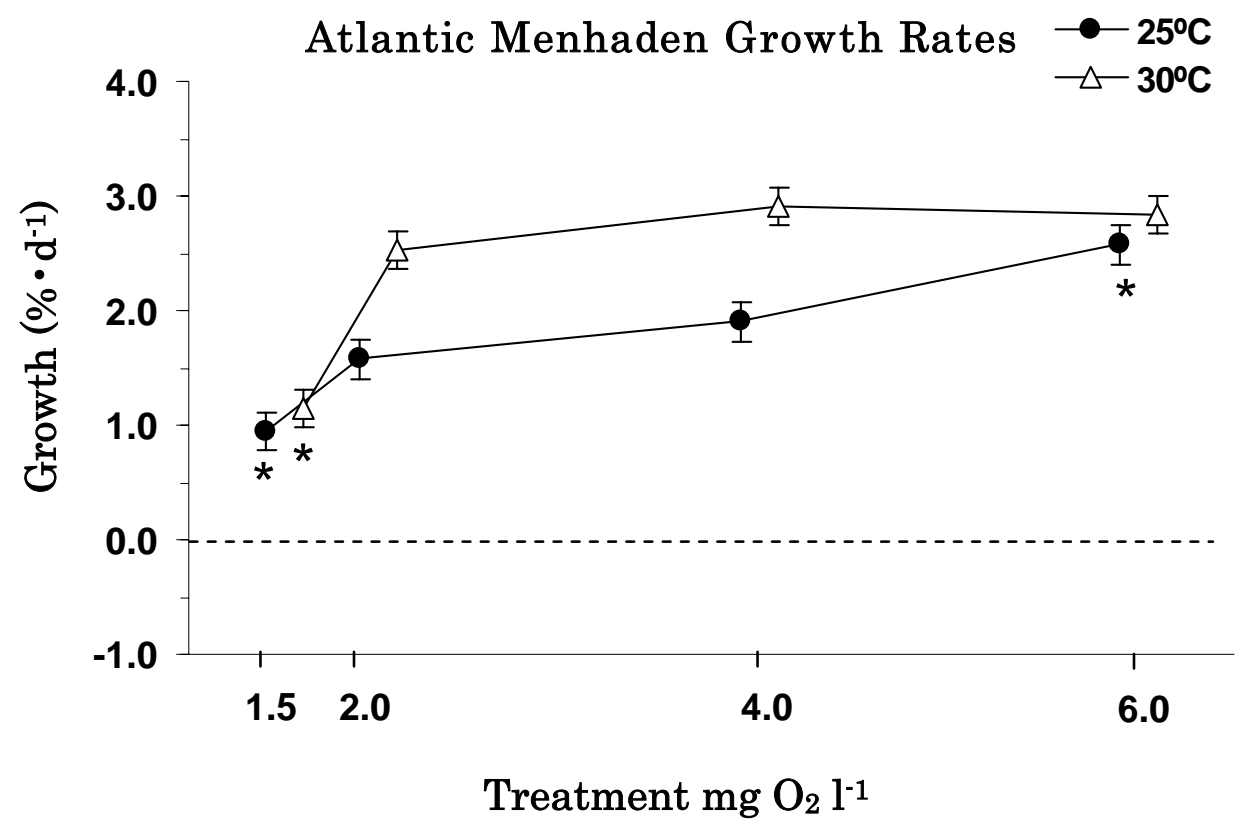

Figure 3.2 Growth rates of Atlantic menhaden at $25^{\circ} \mathrm{C}$ and $30^{\circ} \mathrm{C}$. Atlantic menhaden grew faster at $30^{\circ} \mathrm{C}$ (open triangles) than at $25^{\circ} \mathrm{C}$ (solid circles), $\mathrm{p}=0.0001$. Overall growth rates were reduced at $1.5 \mathrm{mg} \mathrm{O}_{2} \mathrm{l}^{-1}, \mathrm{p}<0.0001$. This effect was due to the significant $(\mathrm{p}=0.05)$ effect of low DO at both $25^{\circ} \mathrm{C}$ and $30^{\circ} \mathrm{C}$, where growth was reduced by $63 \%$ and $60 \%$, respectively, as indicated by asterisks. At $25^{\circ} \mathrm{C}$, growth at $6.0 \mathrm{mg} \mathrm{O}_{2} \mathrm{l}^{-1}$ was higher, $\mathrm{p}=0.05$, than growth at all other treatments, also indicated by an asterisk. 


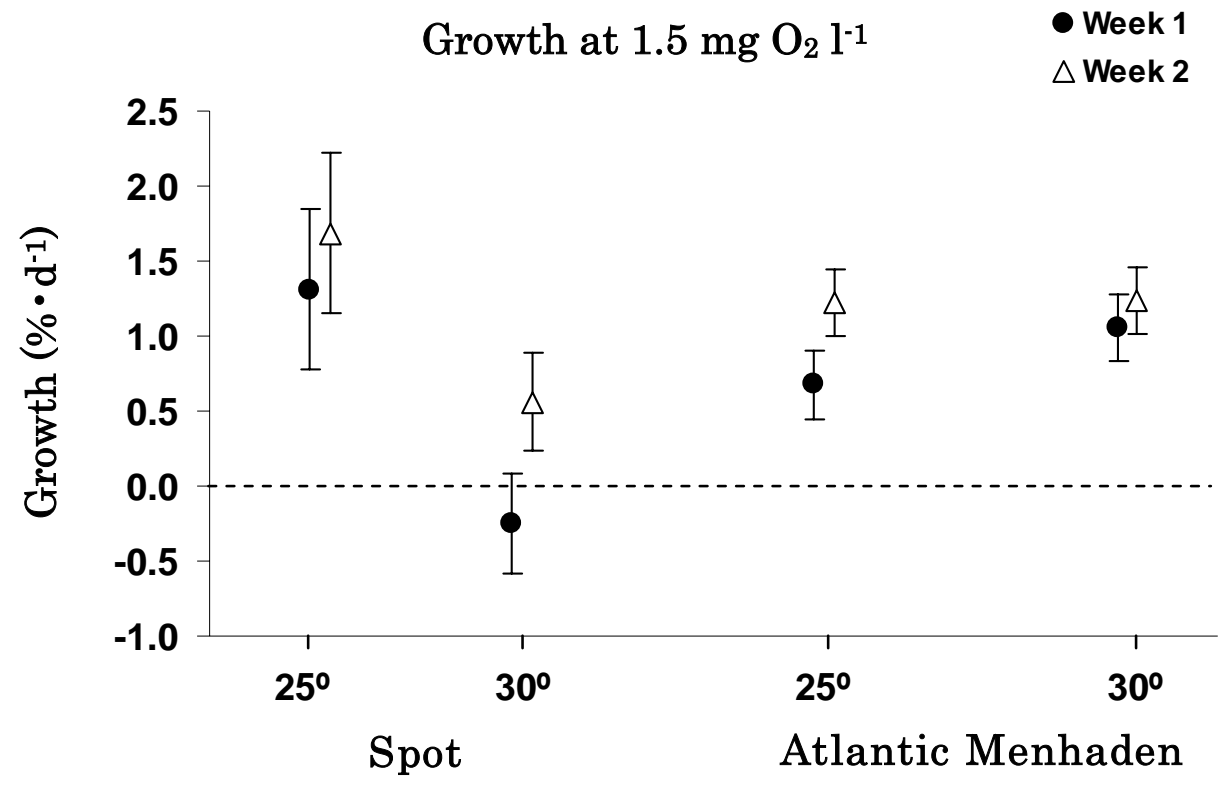

Figure 3.3 Evidence of acclimation in spot and Atlantic menhaden. In every trial, growth increased marginally from week 1 (solid circle) to week 2 (open triangle). 


\section{Discussion}

The objectives of this study were to determine if growth rates of juvenile spot and Atlantic menhaden were affected by sublethal hypoxia, and if there was an effect, to investigate whether there was a graded response as DO declined, or a threshold response where growth rates were only affected after the DO dropped to a certain concentration. This study also examined whether temperature interacted with DO concentration to affect growth rates, and determined whether growth rates changed over a two-week period of hypoxic exposure.

Juvenile spot and Atlantic menhaden experienced a significant reduction in growth rate at the $1.5 \mathrm{mg} \mathrm{O}_{2} \mathrm{l}^{-1}$ treatment level in all experiments. In three of the four trials there was a threshold response whereby growth rates declined sharply below $2.0 \mathrm{mg} \mathrm{O}_{2} \mathrm{l}^{-1}$. In other hypoxia studies on juvenile marine fish significant reductions in growth were observed at higher DO concentrations. For example, Bejda et al (1992) found a significant reduction in growth rate of juvenile winter flounder (Pseudopleuronectes americanus) at $2.2 \mathrm{mg} \mathrm{O}_{2} \mathrm{l}^{-1}$ and $19^{\circ} \mathrm{C}$. Juvenile southern flounder (Paralichthys lethostigma) experienced reduced growth rates at $2.8 \mathrm{mg} \mathrm{O}_{2} \mathrm{l}^{-1}$ and $22^{\circ} \mathrm{C}$ (Taylor, 2001). At $15^{\circ} \mathrm{C}$, significant growth reductions were observed for juvenile plaice (Pleuronectes platessa) at $30 \%$ $\mathrm{O}_{2}$ saturation ( $\left.3.0 \mathrm{mg} \mathrm{O}_{2} \mathrm{l}^{-1}\right)$ and for juvenile dab (Limanda limanda) at 30\% 
and 50\% ( 5.0 $\left.\mathrm{mg} \mathrm{O}_{2} \mathrm{l}^{-1}\right)$ (Petersen and Pihl, 1995). Secor and Gunderson (1998) observed growth rates in juvenile Atlantic sturgeon (Acipenser oxyrinchus) in normoxic water $\left(7.0 \mathrm{mg} \mathrm{O}_{2} \mathrm{l}^{-1}\right)$ at $19^{\circ} \mathrm{C}$ and $26^{\circ} \mathrm{C}$ that were 2.9 times higher than growth rates at $3.0 \mathrm{mg} \mathrm{O}_{2} \mathrm{l}^{-1}$. Juvenile spot and Atlantic menhaden did not experience significant growth reductions until DO levels declined below $2.0 \mathrm{mg} \mathrm{O}_{2} \mathrm{l}^{-1}$ at $25^{\circ} \mathrm{C}$ and $30^{\circ} \mathrm{C}$, suggesting that they are less sensitive to hypoxia than flatfish, which were the focal species of the majority of the aforementioned studies.

The growth rates I observed for spot and Atlantic menhaden under normoxic conditions were fairly similar to growth rates observed in the field. Growth rates of juvenile Atlantic menhaden have been estimated to be 3.8 $\% \cdot d^{-1}$ (Peters and Schaaf, 1981), whereas in this study the average growth rate of Atlantic menhaden in normoxic water was $2.7 \% \cdot \mathrm{d}^{-1}$. Weinstein and Walters (1981) determined the daily growth increment of juvenile spot in the Cape Fear River Estuary, North Carolina to be $0.33 \mathrm{~mm} \cdot \mathrm{d}^{-1}$ (TL). Juvenile spot in this study grew faster, $0.45 \mathrm{~mm} \cdot \mathrm{d}^{-1}(\mathrm{TL})$, presumably due to unlimited food provided in the experiments.

Temperature did have an effect on growth rates in both spot and Atlantic menhaden, as expected given basic metabolic principles. The faster growth rate of juvenile spot at $25^{\circ} \mathrm{C}$ versus $30^{\circ} \mathrm{C}$ suggested that $30^{\circ} \mathrm{C}$ is higher than the thermal optimum for growth of spot. According to Jobling's (1981) 
equation for the relationship between lethal temperature and growth optimum, spot's optimal growth temperature is $27.9^{\circ} \mathrm{C}$. Additionally, $30^{\circ} \mathrm{C}$ is relatively close to $35^{\circ} \mathrm{C}$, the ultimate upper incipient lethal temperature for spot (Hartwell, 1976; Hodson, et al., 1981a).

Atlantic menhaden, however, grew faster at $30^{\circ} \mathrm{C}$ than $25^{\circ} \mathrm{C}$, suggesting that $30^{\circ} \mathrm{C}$ is closer to the thermal optimum for growth in Atlantic menhaden. I was unable to find a study evaluating the optimal growth temperature for Atlantic menhaden but there are investigations of metabolic rates and bioenergetics of Atlantic menhaden that suggest that $30^{\circ} \mathrm{C}$ is close to their thermal optimum. Hettler (1976) indicated that the metabolic rate of Atlantic menhaden continues to increase as temperature rises above $25^{\circ} \mathrm{C}$. Luo et al. (2001) found that swimming speed, which is correlated with consumption rates in filter-feeding fishes (Durbin, et al., 1981), reached a maximum at $30^{\circ} \mathrm{C}$.

Oxygen levels at which growth reductions were observed were similar for both species and at both temperatures. The patterns of growth across DO levels were also similar for both species at both temperatures, even though there was a marginally significant interaction between DO and temperature for Atlantic menhaden.

The mechanism responsible for the reduction in growth is unclear. Such a decline might be caused by a reduction in feeding, which is a common 
response to stress in fish. Consumption rates of spot and Atlantic menhaden were monitored throughout each experiment, but attempts to quantify the amount of food consumed were unsuccessful. In this study fish were fed to excess, but the effect of DO on growth rate might change according to food availability in the field. However, my data are consistent with observed avoidance by these fish in the field of DO levels less than $2.0 \mathrm{mg} \mathrm{O}_{2} \mathrm{l}^{-1}$ (Pihl, et al., 1991; Howell and Simpson, 1994; Nestlerode and Diaz, 1998; Eby, 2001).

The definition of hypoxia is $2.0 \mathrm{mg} \mathrm{O}_{2} \mathrm{l}^{-1}$ or less according to NOAA standards (Bricker, et al., 1999; CENR, 2000) and much of the hypoxia literature (Pihl, et al., 1991; Dauer, et al., 1992; Pihl, et al., 1992; Rosenberg, et al., 1992; Diaz and Rosenberg, 1995). Yet, $2.0 \mathrm{mg} \mathrm{O}_{2} \mathrm{l}^{-1}$ is lower than EPA standards. The EPA has set the saltwater DO criterion for growth at $4.8 \mathrm{mg}$ $\mathrm{O}_{2} \mathrm{l}^{-1}$, and the saltwater DO criterion for adult and juvenile survival is $2.3 \mathrm{mg}$ $\mathrm{O}_{2} \mathrm{l}^{-1}$ (EPA, 2000). Fish show signs of stress at DO levels greater than $2.0 \mathrm{mg}$ $\mathrm{O}_{2} \mathrm{l}^{-1}$. Increased ventilation rate is a common stress response to low DO in many fish and may occur at DO levels higher than $2.0 \mathrm{mg} \mathrm{O}_{2} \mathrm{l}^{-1}$. For instance, increased ventilation rates were observed at $90 \mathrm{~mm} \mathrm{Hg}\left(\sim 6.0 \mathrm{mg} \mathrm{O} \mathrm{O}_{2}\right.$ $\mathrm{l}^{-1}$ ) for flounder (Platichthys flesus) and plaice (Pleuronectes platessa) at $10^{\circ} \mathrm{C}$ (Steffensen, et al., 1982) and at $5.0 \mathrm{mg} \mathrm{O}_{2} \mathrm{l}^{-1}$ for white mullet (Mugil curema) and pinfish (Lagodon rhombiodes) at $25^{\circ} \mathrm{C}$ (Wannamaker and Rice, 2000). 
Spot exhibited an increase in ventilation rate when DO levels were less than or equal to $4.0 \mathrm{mg} \mathrm{O}_{2} \mathrm{l}^{-1}$ at $25^{\circ} \mathrm{C}$ (Wannamaker and Rice, 2000) and their ventilation rate was doubled in comparison to controls at DO concentrations of $3.0 \mathrm{mg} \mathrm{O}_{2} \mathrm{l}^{-1}$ at $25^{\circ} \mathrm{C}$ (Pihl, et al., 1991). This particular adaptation to low DO may allow sufficient delivery of oxygen until DO levels reach $2.0 \mathrm{mg} \mathrm{O}_{2}$ $1^{-1}$. At this point, effects on growth may become noticeable, as seen in this study.

While exposure to hypoxia can result in noticeable reductions in growth, a subsequent increase in DO concentration may result in compensatory growth. In a study on winter flounder (Pseudopleuronectes americanus), Bejda et al. (1992) found that during a 10-week exposure to 2.2 $\mathrm{mg} \mathrm{O} \mathrm{O}_{2} \mathrm{l}^{-1}$ at $19^{\circ} \mathrm{C}$, winter flounder exhibited a depressed growth rate in comparison to the control. After the 10-week exposure, DO levels were increased to $7.2 \mathrm{mg} \mathrm{O}_{2} \mathrm{l}^{-1}$ for five weeks. During the five week recovery period, average growth rates of winter flounder increased over two and a half times their rates during the exposure to $2.2 \mathrm{mg} \mathrm{O}_{2} \mathrm{l}^{-1}$. Thus, compensatory growth mechanisms may potentially mitigate negative impacts of hypoxia on growth rates. However, even though winter flounder experienced increased growth rates after DO levels were increased, their mean length still lagged 3 to 4 weeks behind the control. Additionally, in the field, there is no guarantee that DO levels will remain high in order to accommodate 
compensatory growth, nor is there any guarantee that there will be enough food resources to fuel such high growth for an extended period of time.

Hypoxia is a naturally occurring phenomenon in estuaries (Stanley, 1992; Diaz and Rosenberg, 1995) and estuary-dependent fish have evolved adaptations to deal with reductions in DO levels (Howell and Simpson, 1994; Diaz and Rosenberg, 1995; Crocker and Cech, 1997). In addition to increased ventilation rates, fish exhibit other short-term responses to hypoxia such as changes in activity levels (Breitburg, et al., 1994; Schurmann and Steffensen, 1994; Crocker and Cech, 1997; Chabot and Dutil, 1999; Weltzien, et al., 1999; Domenici, et al., 2000; Zhou, et al., 2000) and changes in hematocrit levels (Cameron, 1970; Taylor, 2001). These adaptations may explain why the DO level at which growth effects were observed for spot and Atlantic menhaden is close to their lethal threshold limits. Burton et al. (1980) determined lethal threshold limits of spot and Atlantic menhaden at $28^{\circ} \mathrm{C}$ to be 0.7 and $1.1 \mathrm{mg} \mathrm{O}_{2} \mathrm{l}^{-1}$, respectively.

For spot and Atlantic menhaden, it appears that short-term responses to hypoxia were not sufficient to offset the effects of hypoxia at DO levels less than $2.0 \mathrm{mg} \mathrm{O}_{2} \mathrm{l}^{-1}$, because growth rates were sharply reduced in the first week of exposure to $1.5 \mathrm{mg} \mathrm{O}_{2} \mathrm{l}^{-1}$. However, both species apparently have longer-term responses that adjust to hypoxic exposure because growth rates of fish exposed to $1.5 \mathrm{mg} \mathrm{O}_{2} \mathrm{l}^{-1}$ increased in week 2. According to the general 
adaptation syndrome model described by Selye (1956) and then adapted to fish bioenergetics by Beyers et al. (1999), fish adjusting to a stressor have additional metabolic costs added to their energy budgets. Thus a reduction in growth is typical. The response of juvenile spot and Atlantic menhaden was consistent with this model as evidenced by reduced growth over a two-week period. However, during the second week of exposure to $1.5 \mathrm{mg} \mathrm{O}_{2} \mathrm{l}^{-1}$, growth rates in all trials increased, although they were still depressed in comparison to the other treatment levels. This increase during the second week of exposure suggests that spot and Atlantic menhaden have some mechanism for partially adapting to DO levels less than $2.0 \mathrm{mg} \mathrm{O}_{2} \mathrm{l}^{-1}$ which does not require a continued increase in metabolic expenditures.

One such mechanism has been described by Weber and Lykkeboe (1978). They found that during hypoxia, carp (Cyprinus carpio) had reduced levels of erythrocytic nucleoside triphosphates (NTP), specifically adenosine triphosphate (ATP) and guanosine triphosphate (GTP). Such a reduction in NTP concentrations led to higher oxygen affinity and lower $\mathrm{pH}$ sensitivity of hemoglobin. A later study suggests that GTP concentrations may have more of an influence on hemoglobin-oxygen affinity than ATP, and the authors proposed that fish which have evolved in a variable environment have higher GTP levels, presumably as a back-up oxygen supply mechanism (Jensen and Weber, 1985). Weber and Lykkeboe (1978) found that NTP levels are rapidly 
reduced within the first two days of exposure to hypoxia, but that it took six or more days for the reduction in NTP concentrations to level off. Thus, oxygen affinity of hemoglobin was at its highest after at least six days. NTP concentrations continued to be reduced throughout the duration of the study which was 50 days. I was unable to find studies investigating erythrocytic levels of NTP in either spot or Atlantic menhaden, but this example gives one plausible explanation for the initial decrease in growth of fish exposed to 1.5 mg $\mathrm{O}_{2} \mathrm{l}^{-1}$ during week 1 , followed by a marginal increase in growth during week 2 .

Estuary-dependent fishes that are adapted to low DO exposure may be able to take advantage of hypoxic events. Studies investigating benthic infauna responses to low DO have found that polychaetes and clams will decrease their burrow depth and clams will increase their siphon length during hypoxic events (Pihl, et al., 1992; Rosenberg, et al., 1992; Nestlerode and Diaz, 1998; Taylor and Eggleston, 2000). This infaunal response to hypoxia provides easy prey items for benthic foragers like spot. Additionally, high densities of plankton have been found at or just the below the pycnocline in the Los Angeles Bight (Lasker, 1975) and in the Neuse River, North Carolina (C. Taylor, unpub. data). In estuarine systems, the pycnocline that develops during the summer is usually the upper boundary of hypoxic waters. C. Taylor (unpub. data) has found that juvenile Atlantic menhaden, bay 
anchovy, and Atlantic silverside congregate near the pycnocline and that some may make feeding forays into the hypoxic waters below the pycnocline where DO levels are $2.0 \mathrm{mg} \mathrm{O}_{2} \mathrm{l}^{-1}$ or less. So it is possible that both juvenile spot and Atlantic menhaden may enter hypoxic waters in order to feed on larger prey items or in areas of high prey concentration.

Feeding by estuary-dependent fishes is an important mechanism controlling energy flow through estuarine systems (Weinstein, 1979;

Weinstein, et al., 1980; Gottlieb, 1998). While juvenile fish inhabit estuarine systems they consume nutrients and convert them to biomass. When fish migrate out of the estuary, they take with them all of the nutrients and energy they have accumulated as biomass. Thus the migratory habit of estuarine fishes is an important link which couples estuaries with nearshore ocean environments. Hypoxia has the potential to dramatically influence energy transfer from estuarine systems to nearshore environments (Pihl, et al., 1992; Breitburg, et al., 1997). Hypoxia can influence growth directly and indirectly. First, growth rates can be directly affected if fish become trapped in areas of hypoxic waters. In some years the extent of hypoxia can be so large that shallow refuges are unavailable (Eby, 2001), or strong upwelling events may trap fish in hypoxic waters (Paerl, et al., 1998; 1999). Second, if shallow refuges are available during hypoxic events and fish crowd into shallow waters to avoid low DO, there may be indirect effects of hypoxia on 
growth rates via density-dependent effects on growth (Eby, 2001). If growth is reduced either directly or indirectly due to hypoxia, fish will have converted less nutrients into biomass, thus, there will be less energy exported from the estuary as fish migrate to nearshore habitats.

Reductions in growth rates of estuary-dependent fishes may also impact export of biomass by reducing the number of individuals recruiting to the adult stock. In fish and other taxa which go through ontogenetic shifts, mortality rates are size-dependent and predators are the primary means of early life history mortality (Werner and Gilliam, 1984). Smaller individuals are more susceptible to predation because they are vulnerable to a larger number of potential predators. As an organism grows it passes through predator fields, continually decreasing the number of predators that are capable of capturing and ingesting it (Werner and Gilliam, 1984). Anything that reduces growth rates of juvenile fish will increase the risk of predation. Small variations in mortality could account for large changes in year-class strength (Sissenwine, 1984). In this manner, growth and mortality are intertwined so that factors affecting growth may indirectly control recruitment and population size. Therefore, reductions in growth caused by environmental factors, such as hypoxia, have the potential to reduce recruitment and production in commercially and recreationally important species (Anderson, 1988). 


\section{References}

Anderson, J.T., 1988. A review of size dependent survival during pre-recruit stages of fishes in relation to recruitment. Journal of Northwest Atlantic Fishery Science 8, 55-66.

Bejda, A.J., Phelan, B.A., Studholme, A.L., 1992. The effect of dissolved oxygen on the growth of young-of-the-year winter flounder, Pseudopleuronectes americanus. Environmental Biology of Fishes 34, 321-327.

Beyers, D.W., Rice, J.A., Clements, W.H., Henry, C.J., 1999. Estimating physiological cost of chemical exposure: integrating energetics and stress to quantify toxic effects in fish. Canadian Journal of Fisheries and Aquatic Sciences 56, 814-822.

Breitburg, D.L., Loher, T., Pacey, C.A., Gerstein, A., 1997. Varying effects of low dissolved oxygen on trophic interactions in an estuarine food web. Ecological Monographs 67, 489-507.

Breitburg, D.L., Steinberg, N., DuBeau, S., Cooksey, C., Houde, E.D., 1994. Effects of low dissolved oxygen on predation on estuarine fish larvae. Marine Ecology Progress Series 104, 235-246.

Bricker, S.B., Clement, C.G., Pirhalla, D.E., Orlando, S.P., Farrow, D.R.G., 1999. National estuarine eutrophication assessment: Effects of nutrient enrichment in the nation's estuaries. NOAA, National Ocean Service, Special Projects Office and the National Centers for Coastal Ocean Science, Silver Spring, MD, pp. 71.

Burton, D.T., Richardson, L.B., Moore, C.J., 1980. Effect of oxygen reduction rate and constant low dissolved oxygen concentrations on two estuarine fish. Transactions of the American Fisheries Society 109, $552-557$. 
Cameron, J.N., 1970. The influence of environmental variables on the hematology of pinfish (Lagodon rhomboides) and striped mullet (Mugil cephalus). Comparative Biochemistry and Physiology 32, 175-192.

CENR, 2000. Integrated assessment of hypoxia in the Northern Gulf of Mexico. National Science and Technology Council Committee on Environment and Natural Resources, Washington, D.C.

Chabot, D., Dutil, J.-D., 1999. Reduced growth of Atlantic cod in non-lethal hypoxic conditions. Journal of Fish Biology 55, 472-491.

Crocker, C.E., Cech, J., J., Jr, 1997. Effects of environmental hypoxia on oxygen consumption rate and swimming activity in juvenile white sturgeon, Acipenser transmontanus, in relation to temperature and life intervals. Environmental Biology of Fishes 50, 383-389.

Dauer, D.M., Rodi, A.J., Jr, Ranasinghe, J.A., 1992. Effects of low dissolved oxygen events on the macrobenthos of the lower Chesapeake Bay. Estuaries 15, 384-391.

Deubler, E.E., Jr, Posner, G.S., 1963. Response of postlarval flounders, Paralichthys lethostigma, to water of low oxygen concentrations. Copeia 2, 312-317.

Diaz, R.J., Rosenberg, R., 1995. Marine benthic hypoxia: A review of its ecological effects and the behavioural responses of benthic macrofauna. Oceanography and Marine Biology: an annual review 33, 245-303.

Domenici, P., Steffensen, J.F., Batty, R.S., 2000. The effect of progressive hypoxia on swimming activity and schooling in Atlantic herring. Journal of Fish Biology 57, 1526-1538.

Durbin, A.G., Durbin, E.G., Verity, P.G., Smayda, T.J., 1981. Voluntary swimming speeds and respiration rates of a filter-feeding planktivore, the Atlantic menhaden, Brevoortia tyrannus (Pisces: Clupeidae). Fishery Bulletin 78, 877-886. 
Eby, L.A., 2001. Response of a fish community to frequent and infrequent disturbances in an estuarine ecosystem, Ecology Program. Duke University, pp. 276.

EPA, U.S., 2000. Ambient aquatic life water criteria for dissolved oxygen(saltwater): Cape Cod to Cape Hatteras. U.S. Environmental Protection Agency. Office of Water. EPA-822-R-00-012, Washington, DC.

Fry, F.E.J., 1951. A fractionating column to provide water of various dissolved oxygen content. Canadian Journal of Technology 29, 144-146.

Gottlieb, S.J., 1998. Nutrient removal by age-0 Atlantic menhaden (Brevoortia tyrannus) in Chesapeake Bay and implications for seasonal management of the fishery. Ecological Modelling 112, 111130.

Grecay, P.A., Stierhoff, K.S., manuscript submitted. A device for simultaneously controlling multiple treatment levels of dissolved oxygen in laboratory experiments. Journal of Experimental Marine Biology and Ecology.

Hales, L.S., Van Den Avyle, M.J., 1989. Species Profiles: life histories and environmental requirements of coastal fishes and invertebrates (South Atlantic)--spot. U.S. Fish and Wildlife Service Biological Report 82(11.91). U.S. Army Corps of Engineers TR EL-82-4, pp. 24.

Hartwell, S.I., 1976. The effect of cycling acclimation temperature on the thermal shock resistance of postlarval and juvenile spot, Leiostomus xanthurus Lacepede., Department of Zoology. North Carolina State University, Raleigh, pp. 25.

Hettler, W.F., 1976. Influence of temperature and salinity on routine metabolic rate and growth of young Atlantic menhaden. Journal of Fish Biology 8, 55-65. 
Hodson, R.G., Fechhelm, R.G., Monroe, R.J., 1981a. Upper temperature tolerance of the spot, Leiostomus xanthursus, from the Cape Fear River Estuary, North Carolina. Estuaries 4, 345-356.

Howell, P., Simpson, D., 1994. Abundance of marine resources in relation to dissolved oxygen in Long Island Sound. Estuaries 17, 394-402.

Jensen, F.B., Weber, R.E., 1985. Kinetics of the acclimational responses of tench to combined hypoxia and hypercapnia. Journal of Comparative Physiology 156, 197-203.

Jobling, M., 1981. Temperature tolerance and the final preferendum--rapid methods for the assessment of optimum growth temperatures. Journal of Fish Biology 19, 439-455.

Kramer, D.L., 1987. Dissolved oxygen and fish behavior. Environmental Biology of Fishes 18, 81-92.

Lasker, R., 1975. Field criteria for survival of anchovy larvae: the relation between inshore chlorophyll maximum layers and successful first feeding. Fishery Bulletin 73, 453-462.

Luo, J., Hartman, K.J., Brandt, S.B., Cerco, C.F., Ripptoe, T.H., 2001. A spatially-explicit approach for estimating carrying capacity: An application for the Atlantic menhaden (Brevoortia tyrannus) in Chesapeake Bay. Estuaries 24, 545-556.

Nestlerode, J.A., Diaz, R.J., 1998. Effects of periodic environmental hypoxia on predation of a tethered polychaete, Glycera americana: implications for trophic dynamics. Marine Ecology Progress Series 172, 185-195.

Paerl, H.W., Pinckney, J.L., Fear, J.M., Peierls, B.L., 1998. Ecosystem responses to internal and watershed organic matter loading: consequences for hypoxia in the eutrophying Neuse River Estuary, North Carolina, USA. Marine Ecology Progress Series 166, 17-25. 
Paerl, H.W., Pinckney, J.L., Fear, J.M., Peierls, B.L., 1999. Fish kills and bottom-water hypoxia in the Neuse River and Estuary: reply to Burkholder et al. Marine Ecology Progress Series 186, 307-309.

Peters, D.S., Schaaf, W.E., 1981. Food requirements and sources for juvenile Atlantic menhaden. Transactions of the American Fisheries Society 110, 317-324.

Petersen, J.K., Pihl, L., 1995. Responses to hypoxia of plaice, Pleuronectes platessa, and dab, Limanda limanda, in the south-east Kattegat: distribution and growth. Environmental Biology of Fishes 43, 311-321.

Pihl, L., 1994. Changes in the diet of demersal fish due to eutrophicationinduced hypoxia in the Kattegat, Sweden. Canadian Journal of Fisheries and Aquatic Sciences 51, 321-336.

Pihl, L., Baden, S.P., Diaz, R.J., 1991. Effects of periodic hypoxia on distribution of demersal fish and crustaceans. Marine Biology 108, 349-360.

Pihl, L., Baden, S.P., Diaz, R.J., Schaffner, L.C., 1992. Hypoxia-induced structural changes in the diet of bottom-feeding fish and Crustacea. Marine Biology 112, 349-361.

Rogers, S.G., Van Den Avyle, M.J., 1983. Species profiles: life histories and environmental requirements of coastal fishes and invertebrates (South Atlantic)--Atlantic menhaden. U.S. Fish and Wildlife Service, Division of Biological Services, FWS/OBS-82/11.11. U.S. Army Corps of Engineers, TR EL-82-4, pp. 20.

Rosenberg, R., Loo, L.-O., Moller, P., 1992. Hypoxia, salinity and temperature as structuring factors for marine benthic communities in a eutrophic area. Netherlands Journal of Sea Research 30, 121-129. 
Schurmann, H., Steffensen, J.F., 1994. Spontaneous swimming activity of Atlantic cod, Gadus morhua, exposed to graded hypoxia at three temperatures. The Journal of Experimental Biology 197, 129-142.

Schurmann, H., Steffensen, J.F., 1997. Effects of temperature, hypoxia and activity on the metabolism of juvenile Atlantic cod. Journal of Fish Biology 50, 1166-1180.

Secor, D.H., Gunderson, T.E., 1998. Effects of hypoxia and temperature on survival, growth, and respiration of juvenile Atlantic sturgeon, Acipenser oxyrinchus. Fishery Bulletin 96, 603-613.

Selye, H., 1956. The stress of life. McGraw-Hill Book Company, New York.

Sissenwine, M.P., 1984. Why do fish populations vary? In: May, R.M. (Ed.), Exploitation of marine communities. Springer-Verlag, Berlin, Heidelberg, New York, Tokyo, pp. 59-94.

Stanley, D.W., 1992. Historical trends: water quality and fisheries, Albemarle-Pamlico Sounds, with emphasis on the Pamlico River Estuary. University of North Carolina Sea Grant College Program. Institute for Coastal and Marine Resources. UNC-SG-92-04., Greenville, NC, pp. 215.

Steffensen, J.F., Lomholt, J.P., Johansen, K., 1982. Gill ventilation and O2 extraction during graded hypoxia in two ecologically distinct species of flatfish, the flounder (Platichthys flesus) and the plaice (Pleuronectes platessa). Environmental Biology of Fishes 7, 157-163.

Taylor, D.L., Eggleston, D.B., 2000. Effects of hypoxia on an estuarine predator-prey interaction: foraging behavior and mutual interference in the blue crab Callinectes sapidus and the infaunal clam prey Mya arenaria. Marine Ecology Progress Series 196, 221-237. 
Taylor, J.C., 1999. Physiological performance of juvenile southern flounder, Paralichthys lethostigma, in chronic and periodic hypoxia, Zoology. North Carolina State University, Raleigh, pp. 50.

Taylor, J.C., 2001. Physiological performance of juvenile southern flounder, Paralichthys lethostigma (Jordan and Gilbert, 1884), in chronic and episodic hypoxia. Journal of Experimental Marine Biology and Ecology $258,195-214$.

Wannamaker, C.M., Rice, J.A., 2000. Effects of hypoxia on movements and behavior of selected estuarine organisms from the southeastern United States. Journal of Experimental Marine Biology and Ecology 249, 145163.

Warlen, S.M., Chester, A.J., 1985. Age, growth, and distribution of larval spot, Leiostomus xanthurus, off North Carolina. Fishery Bulletin 83, 587-599.

Weber, R.E., Lykkeboe, G., 1978. Hypoxic adaptation of hemoglobin function in carp. Journal of Comparative Physiology 128, 127-137.

Weinstein, M.P., 1979. Shallow marsh habitats as primary nurseries for fishes and shellfish, Cape Fear River, North Carolina. Fishery Bulletin 77, 339-357.

Weinstein, M.P., Walters, M.P., 1981. Growth, survival, and production in young-of-year populations of Leiostomus xanthurus Lacepede residing in tidal creeks. Estuaries 4, 185-197.

Weinstein, M.P., Weiss, S.L., Walters, M.F., 1980. Multiple determinants of community structure in shallow marsh habitats, Cape Fear River Estuary, North Carolina, USA. Marine Biology 58, 227-243.

Weltzien, F.-A., Doving, K.B., Carr, W.E.S., 1999. Avoidance reaction of yolksac larvae of the inland silverside, Menidia beryllina (Atherinidae), to hypoxia. The Journal of Experimental Biology 202, 2869-2876. 
Werner, E.E., Gilliam, J.F., 1984. The ontogenetic niche and species interactions in size-structured populations. Annual Review of Ecology and Systematics 15, 393-425.

Zhou, B.S., Wu, R.S.S., Randall, D.J., Lam, P.K.S., Ip, Y.K., Chew, S.F., 2000. Metabolic adjustments in the common carp during prolonged hypoxia. Journal of Fish Biology 57, 1160-1171. 